Joyful Learning Journal

\title{
HUBUNGAN MINAT DAN DISIPLIN BELAJAR DENGAN HASIL BELAJAR MUATAN IPS
}

\section{Kusuma Anggriyani ${ }^{凶}$, Isa Ansori}

Jurusan Pendidikan Guru Sekolah Dasar, Fakultas Ilmu Pendidikan, Universitas Negeri Semarang, Indonesia

\section{Info Artikel Abstrak \\ Sejarah Artikel: \\ Tujuan penelitian ini adalah untuk menguji hubungan yang positif dan signifikan antara minat dan disiplin belajar Diterima Oktober 2020 dengan hasil belajar muatan IPS siswa kelas IV SDN Gugus Ahmad Yani Kabupaten Pekalongan. Penelitian ini Disuakan penelitian kuantitatif jenis korelasi. Populasi berjumlah 151 siswa dengan jumlah sampel 106 siswa. Disetujui November 2020 Teknik pengambilan sampel menggunakan Proportional Random Sampling. Teknik pengumpulan data dengan 2020 wawancara, observasi, angket dan dokumentasi. Uji instrumen dilakukan dengan uji validitas dan uji reliabilitas. 2020 Teknik analisis data menggunakan analisis statistik deskriptif dan analisis korelasi product moment. Hasil analisis data \\ Keywords: penelitian ini menunjukkan terdapat hubungan yang positif dan signifikan antara minat dan disiplin belajar dengan $\begin{array}{ll}\text { Keywords: } & \text { hasil belajar muatan IPS, nilai rhitung }=0,679 \text { dan termasuk kategori kuat serta berkontribusi sebesar } 46,1 \% \text {. Simpulan } \\ \text { Learning Disiplin Learning } & \text { dari penelitian ini adalah terdapat hubungan yang positif dan signifikan antara minat dan disiplin belajar dengan hasil }\end{array}$ Outcomes \\ Learning Interest belakar muatan IPS siswa kelas IV SDN Gugus Ahmad Yani Kabupaten Pekalongan.}

\begin{abstract}
The purpose of this study was to examine the existence of a positive and significant correlation between learning interest and learning discipline with social studies learning outcomes the fourth grade students of the State Elementary School of Ahmad Yani Cluster in Pekalongan Regency. This research was a quantitative type of correlation study. The population was 151 students with a sample of 106 students. The sampling technique used Proportional Random Sampling. The data collection techniques used interviews, observation, questionnaires, and documentations. The instrument test used validity test and reliability test. The data analysis techniques used descriptive analysis and product moment correlation analysis. The results of the data analysis in this study showed there was a positive and significant correlation between learning interest and learning discipline with social studies learning outcomes, Rcount $=0.679$ and includes in a strong category and contributes $46.1 \%$. The conclusion in this study there was a positive and significant correlation between learning interest and learning discipline with social studies learning outcomes the fourth grade students of the State Elementary School of Ahmad Yani Cluster in Pekalongan Regency.
\end{abstract}

(C) 2020 Universitas Negeri Semarang

$\triangle$ Alamat korespondensi:

Pekuncen RT 04 RW 04 Wiradesa Pekalongan

ISSN 2252-6366

E-mail: anggriyanikusuma@gmail.com 


\section{PENDAHULUAN}

Pendidikan merupakan upaya yang dilakukan secara sadar dan terencana yang diwujudkan dalam proses pembelajaran untuk membentuk dan mengembangkan kemampuan, kepribadian, dan potensi siswa agar menjadi manusia yang berguna bagi lingkungan masyarakat dan negara (UU Sistem Pendidikan Nasional No.20 Bab I Pasal 1 tahun 2003). Berdasarkan Berdasarkan Peraturan Menteri Pendidikan Nasional No.22 $\mathrm{Bab}$ II tahun 2006 menjelaskan struktur kurikulum SD/MI terdapat 8 muatan pelajaran (mupel) yang terdiri dari Pendidikan Agama, PKn (Pendidikan Kewarganegaraan), Bahasa Indonesia, IPS (Ilmu Pengetahuan Sosial), IPA (Ilmu Pengetahuan Alam), Matematika, Seni Budaya dan Keterampilan, Pendidikan Jasmani Olahraga, dan Kesehatan, serta muatan lokal, dan pengembangan diri.

IPS merupakan muatan pelajaran gabungan dari IIS (ilmu-ilmu sosial) dan kehidupan manusia yang didalamnya terdapat materi sosiologi, sejarah, ekonomi, antropologi, geografi, hukum, ilmu politik, filsafat, agama dan psikologi (Susanto,2013:139). Kurikulum Pendidikan Dasar Tahun 1993 menyebutkan bahwa IPS mempelajari kehidupan sosial masyarakat yang didasarkan pada bahan kajian sejarah, antropologi, sosiologi, geografi, ekonomi, dan tata negara.

Salah satu cara mengukur tingkat keberhasilan belajar siswa dalam mata pelajaran IPS adalah dengan minat belajar, disiplin belajar dan hasil belajar siswa. Menurut Baharuddin (2015:29), minat ialah kecenderungan, kegairahan, atau keinginan yang besar terhadap sesuatu. Selain minat, disiplin belajar juga memengaruhi hasil belajar muatan IPS siswa. Disiplin (Tu'u, 2008:30) merupakan kesadaran pengendalian diri seseorang terhadap berbagai aturan. Hasil belajar menurut Anitah dkk (2014) yaitu suatu perubahan tingkah laku siswa yang dikelompokan menjadi tiga ranah yaitu penguasaan nilai atau sikap (afektif), pengetahuan (kognitif), dan keterampilan (psikomotorik). Peneliti melakukan prapenelitian di SDN Gugus Ahmad Yani Kabupaten Pekalongan dengan wawancara, observasi, dan dokumentasi terdapat beberapa masalah yang peneliti temukan seperti rendahnya minat belajar siswa. Rendahnya minat belajar ditunjukkan dengan siswa tidak merasa senang saat pembelajaran, siswa tidak bersemangat saat belajar di kelas, siswa tidak aktif saat pembelajaran di kelas, dan siswa tidak mendengarkan saat guru menjelaskan. Kemudian adalah masalah disiplin siswa,
Seperti ada beberapa siswa yang tidak membawa buku pelajaran, siswa belum menyiapkan alat tulis dan buku yang akan digunakan saat proses pembelajaran, ada beberapa siswa yang tidak mengumpulkan tugas tepat waktu, dan siswa kurang konsentrasi saat pembelajaran. Masalahmasalah tersebut kemudian berpengaruh dengan hasil belajar muatan IPS siswa yang rendah. Terdapat 84 siswa (56\%) nilainya masih kurang dari KKM, dan 67 siswa (44\%) nilainya sudah lebih dari KKM.

Jurnal penelitian internasional oleh Tri Dewantari dan Rita (2018) yang menyatakan di sekolah masih ada siswa yang tidak disiplin belajar dan berperilaku tidak sesuai dengan aturan dalam pembelajaran. Selanjutnya penelitian oleh Devika Wasiatul Aulia, Muhammad Khafid \& Masturi (2018) dengan judul "Role of Learning Discipline in Mediating The Influence of Parent's Parenting Towards Student's Learning Achievement", hasil analisis menyatakan terdapat pengaruh signifikan dan positif disiplin belajar melalui prestasi belajar siswa (37,7\%). Penelitian oleh oleh Fitria Kumala Sari, Rakimahwati, dan Yanti Fitria (2019:397405) yang berjudul "Hubungan Minat denga hasil Belajar Peserta Didik Pada Pembelajaran Matematika Kelas VI SDN 25 Jati Tanah Tinggi", menunjukkan terdapat hubungan antara minat dengan hasil belajar peserta didik SDN25 Jati Tanah Tinggi. Penelitian yang dilakukan oleh Rismawati (2017:93-95) yang berjudul "Hubungan antara Disiplin Belajar dengan Hasil Belajar PPKn", dikemukakan dalam penelitian bahwa ada hubungan antara disiplin belajar dengan hasil belajar PKn siswa kelas V SD Inpres Songkolo dengan koefisien sebesar 0,660 berada ditingkat yang kuat. Penelitian lain yang dilakukan Yuli Mulyawati (2019:114) yang berjudul "Pengaruh Disiplin Belajar Terhadap Hasil Belajar Ilmu Pengetahuan Sosial". Hasil penelitian menunjukkan bahwa terdapat pengaruh antara disiplin belajar terhadap hasil belajar IPS.

Tujuan dilaksanakan penelitian ini adalah (1) Menguji hubungan yang positif dan signifikan antara minat belajar dengan hasil belajar muatan IPS siswa kelas IV SDN Gugus Ahmad Yani Kabupaten Pekalongan. (2) Menguji hubungan yang positif dan signifikan antara disiplin belajar dengan hasil belajar muatan IPS siswa kelas IV SDN Gugus Ahmad Yani Kabupaten Pekalongan. (3) Menguji hubungan yang positif dan signifikan antara minat belajar dan disiplin belajar dengan hasil belajar muatan IPS siswa kelas IV SDN Gugus Ahmad Yani Kabupaten Pekalongan. 


\section{METODE PENELITIAN}

Penelitian ini merupakan penelitian kuantitatif dan termasuk jenis korelasi. Subjek dalam penelitian ini adalah siswa kelas IV SDN Gugus Ahmad Yani Kabupaten Pekalongan meliputi SDN 01 Mayangan, SDN 02 Mayangan, SDN Kemplong, SDN Kauman, dan SDN Kampil dengan populasi berjumlah 151 siswa. Teknik pengambilan sampel menggunakan Teknik Proportional Random Sampling dengan sampel sebanyak 106 siswa. Variabel dalam penelitian ini terdiri atas dua variabel bebas yaitu minat belajar dan disiplin belajar, serta satu variabel terikat yaitu hasil belajar muatan IPS, sehingga peneliti menggunakan paradigma ganda dua variable independe

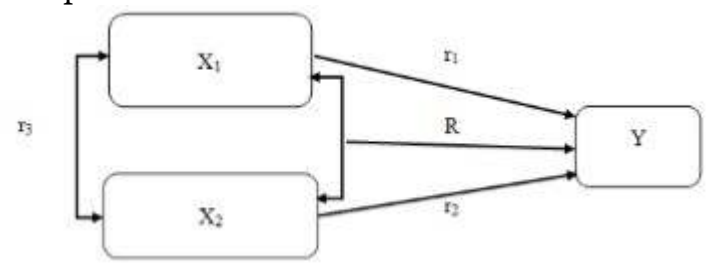

Gambar 1. Desain Penelitian Paradigma Ganda

Teknik pengumpulan data menggunakan wawancara, observasi, angket, dan dokumentasi. Angket dalam penelitian ini digunakan untuk mengetahui informasi tentang minat dan disiplin belajar yang dimiliki oleh masing-masing siswa, sedangkan hasil belajar muatan IPS diperoleh dari hasil Ulangan Harian Semester Genap tahun pelajaran 2019/2020. Uji instrumen dilakukan dengan uji validitas dan uji reliabilitas. Teknik analisis data menggunakan analisis statistic deskriptif dan analisis korelasi product moment.

\section{HASIL DAN PEMBAHASAN}

\section{Hasil Analisis Deskriptif}

Analisis statistik deskriptif digunakan untuk mendeskripsikan data dari masingmasing variabel, meliputi deskripsi data variabel bebas yakni minat belajar dan disiplin belajar serta deskripsi data variabel terikat yakni hasil belajar muatan IPS siswa kelas IV SDN Gugus Ahmad Yani Kabupaten Pekalongan.

\section{Hasil Analisis Deskriptif Variabel Minat Belajar (X1) \\ Data minat belajar diperoleh} berdasarkan angket yang terdiri atas 33 item pernyataan. Hasil angket minat belajar yang terdapat di kelas IV SD Gugus Ahmad Yani
Kabupaten Pekalongan dapat dilihat pada tabel berikut:

Tabel 1 Kategori Minat Belajar

\begin{tabular}{cccc}
\hline Skor & $\begin{array}{c}\text { Jumlah } \\
\text { siswa }\end{array}$ & persentase & kategori \\
\hline $82-100$ & 13 & $12 \%$ & $\begin{array}{c}\text { Sangat } \\
\text { Baik }\end{array}$ \\
& & & Baik \\
$63-81$ & 77 & $73 \%$ & Cukup \\
$44-62$ & 16 & $15 \%$ & Kurang \\
$25-43$ & 0 & $0 \%$ & \\
Jumlah & 106 & $100 \%$ & \\
\hline
\end{tabular}

Sumber: Data Penelitian (tahun 2020)

Rata-rata skor,angket minat,belajar sebesar 71, maka minat belajar siswa kelas IV SDN Gugus Ahmad Yani Kabupaten Semarang termasuk kategori baik.

\section{Hasil Analisis Deskriptif Disiplin Belajar (X2)}

Data disiplin belajar diperoleh berdasarkan angket yang terdiri atas 32 item pernyataan. Disiplin belajar yang terdapat di kelas IV SDN Gugus Ahmad Yani Kabupaten Pekalongan dapat dilihat pada tabel berikut:

Tabel 1 Kategori Disiplin Belajar

\begin{tabular}{cccc}
\hline Skor & $\begin{array}{c}\text { Jumlah } \\
\text { siswa }\end{array}$ & persentase & kategori \\
\hline $82-100$ & 33 & $31 \%$ & $\begin{array}{c}\text { Sangat } \\
\text { Baik }\end{array}$ \\
$63-81$ & 56 & $53 \%$ & Baik \\
$44-62$ & 14 & $13 \%$ & Cukup \\
$25-43$ & 3 & $3 \%$ & Kurang \\
Jumlah & 106 & $100 \%$ & \\
\hline
\end{tabular}

Sumber: Data Penelitian (tahun 2020)

Rata-rata skor,angket disiplin,belajar sebesar 77, maka disiplin belajar siswa kelas IV SDN Gugus Ahmad Yani Kabupaten Pekalongan termasuk kategori baik.

\section{Hasil Analisis Deskriptif Hasil Belajar Muatan IPS (Y)}

Hasil belajar muatan IPS dalam penelitian ini diperoleh dari nilai IPS siswa kelas IV SDN Gugus Ahmad Yani Kabupaten Pekalongan pada Ulangan Harian Semester Genap Tahun pelajaran 2019/2020.

Tabel 3. Kategori Hasil Belajar Muatan IPS

\begin{tabular}{cccc}
\hline Skor & $\begin{array}{c}\text { Jumlah } \\
\text { siswa }\end{array}$ & persentase & kategori \\
\hline $82-100$ & 28 & $26 \%$ & $\begin{array}{c}\text { Sangat } \\
\text { Baik }\end{array}$ \\
$71-85$ & 60 & $57 \%$ & Baik \\
$56-70$ & 18 & $17 \%$ & Cukup \\
$\leq 55$ & 0 & $0 \%$ & Kurang \\
Jumlah & 106 & $100 \%$ & \\
\hline
\end{tabular}

Sumber: Data Penelitian (tahun 2020) 
Rata-rata skor,hasil,belajar muatan IPS sebesar 80, maka hasil belajar siswa kelas IV SDN Gugus Ahmad Yani Kabupaten Pekalongan termasuk kategori baik.

\section{Hasil Uji Prasyarat}

\section{Uji Normalitas}

Uji normalitas dilakukan untuk mengetahui data pada setiap variabel yang dianalisis berdistribusi normal (Sugiyono, 2016). Uji normalitas dalam penelitian ini mengacu pada model uji Kolgomorov-Smirnov. Berdasarkan hasil uji normalitas didapatkan harga signifikansi Asymp.Sig (2-tailed) sebesar 0,200 dimana harga signifikansi tersebut lebih besar dari 0,05. Maka dapat disimpulkan bahwa data berdistribusi normal. Dengan demikian, asumsi atau persyaratan normalitas sudah terpenuhi.

\section{Uji Linieritas}

Uji linieritas variabel minat belajar dengan hasil belajar muatan IPS diperoleh nilai signifikansi Deviation from Linearity 0,968>0,05 maka dapat disimpulkan bahwa antara minat belajar dengan hasil belajar muatan IPS terdapat hubungan yang linier. Sedangkan uji linieritas variabel disiplin belajar dengan hasil belajar muatan IPS diperoleh nilai signifikansi Deviation from Linearity $0,163>0,05$ maka dapat disimpulkan bahwa antara disiplin belajar dengan hasil belajar muatan IPS terdapat hubungan yang linier.

\section{Uji Multikolinieritas}

Dari hasil uji multikolinieritas diketahui bahwa nilai Variance Inflation Factor (VIF) kedua variabel bebas yaitu minat belajar dan disiplin belajar adalah 2,376 < 10 dan nilai Tolerance 0,421 > 0,10 maka dapat disimpulkan bahwa antarvariabel independen tidak terjadi multikolinieritas.

\section{Analisis Hipotesis}

Analisis hipotesis dalam penelitian ini menggunakan analisis korelasi sederhana, analisis korelasi ganda, uji signifikansi (uji F), dan uji koefisien determinasi.

\section{Hubungan Minat Belajar dengan Hasil Belajar Muatan IPS}

Uji korelasi sederhana untuk menguji hubungan minat belajar dengan hasil belajar muatan IPS dalam penelitian ini menggunakan uji korelasi product moment dengan berbantuan program SPSS for Windows seri 22. Hasil perhitungan dapat dilihat pada tabel berikut:
Tabel 4. Hasil Uji Korelasi Minat Belajar dengan Hasil Belajar Muatan IPS

\begin{tabular}{cccc}
\hline rhitung & $\begin{array}{c}\text { Taraf } \\
\text { Kesalahan }\end{array}$ & Sig. & $\begin{array}{c}\text { Uji } \\
\text { Determinasi }\end{array}$ \\
\hline 0,646 & 0,05 & 0,000 & $41,7 \%$ \\
\hline \multicolumn{2}{c}{ Sumber: Data Penelitian (tahun 2020$)$}
\end{tabular}

Tabel 4 menunjukkan bahwa uji korelasi minat belajar dengan hasil belajar muatan IPS diperoleh hasil bahwa nilai $\mathrm{r}_{\text {hitung }}$ yaitu $0,646>0,195$. Hasil tersebut menunjukkan angka yang positif dan nilai koefisien ( $r$ ) termasuk kategori kuat. Pada taraf signifikansi 0,05 diketahui nilai signifikansi dari tabel 4 yaitu $0,00(0,00 \leq 0,05)$, sehingga korelasi dikatakan signifikan. Hasil koefisien determinasi, diperoleh kontibusi minat belajar dengan hasil belajar IPS sebesar 41,7\% sedangkan sisanya $58,3 \%$ dipengaruhi faktor lain.

Hasil penelitian ini diperkuat dengan penelitian yang dilakukan oleh Nuristiqomah dan Susilo (2018:55-63) dengan judul "Hubungan Minat Siswa dan Lingkungan Masyarakat Terhadap Hasil Belajar IPS Kelas V", menyebutkan bahwa ada hubungan yang signifikan dan positif antara minat siswa terhadap hasil belajar IPS dengan nilai rhitung sebesar 0,627 dengan nilai signifikansi $0,00<$ 0,05 , ada hubungan yang positif dan signifikan antara lingkungan masyarakat terhadap hasil belajar IPS dengan nilai rhitung sebesar 0,643 dengan nilai signifikansi $0,00<0,05$, ada hubungan yang positif dan signifikan antara minat siswa dan lingkungan masyarakat terhadap hasil belajar IPS dengan nilai Rhitung sebesar 0,747, dan Fhitung sebesar 79,679.

Penelitian yang dilakukan oleh Mikael Nesi dan Maik Akobiarek (2018:80-94) dengan judul "Pengaruh Minat dan Pengunaan Metode Terhadap Hasil Belajar IPA Biologi Siswa Kelas 1 SMP Negeri 2 Jayapura". Hasil penelitiannya ada pengaruh yang sangat signifikan antara metode pembelajaran dan minat terhadap hasil belajar IPA Biologi siswa dengan Fhitung $=3.776>$ Ftabel $=2.46$. Penelitian Risa Triarisanti dan Pupung Purnawarman (2019:130-135) dengan judul "The Influence Of Interest And Motivation On College Students' Language And Art Appreciation Learning Outcomes". Hasil penelitiannya menunjukkan bahwa minat dan motivasi mempunyai pengaruh yang signifikan terhadap hasil belajar siswa.

Berdasarkan penjelasan di atas dapat disimpulkan bahwa terdapat hubungan yang positif dan signifikan antara minat belajar dengan hasil belajar muatan IPS siswa kelas IV SDN Gugus Ahmad Yani Kabupaten Pekalongan. Artinya, semakin tinggi tingkat minat belajar maka akan semakin baik pula 
hasil belajar muatan IPS yang diperoleh dan sebaliknya.

\section{Hubungan Disiplin Belajar dengan Hasil Belajar Muatan IPS}

Uji korelasi sederhana untuk menguji hubungan disiplin belajar dengan hasil belajar muatan IPS dalam penelitian ini menggunakan uji korelasi product moment dengan berbantuan program SPSS for Windows seri 22. Hasil perhitungan dapat dilihat pada tabel berikut:

Tabel 5 Hasil Uji Korelasi Disiplin Belajar dengan Hasil Belajar Muatan IPS

\begin{tabular}{cccc}
\hline $\mathbf{r}_{\text {hitung }}$ & $\begin{array}{c}\text { Taraf } \\
\text { Kesalahan }\end{array}$ & Sig. & $\begin{array}{c}\text { Uji } \\
\text { Determinasi }\end{array}$ \\
\hline 0,628 & 0,05 & 0,000 & $39,4 \%$ \\
\hline \multicolumn{4}{c}{ Sumber: Data Penelitian (tahun 2020$)$}
\end{tabular}

Tabel 5 menunjukkan bahwa uji korelasi disiplin belajar dengan hasil belajar muatan IPS diperoleh hasil bahwa nilai $r_{\text {hitung }}$ yaitu 0,628 . Hasil tersebut menunjukkan angka yang positif dan nilai koefisien korelasi $(r)$ pada penelitian termasuk ke dalam kategori kuat. Pada taraf signifikansi 0,05 diketahui nilai signifikansi dari tabel 5 yaitu yaitu $0,000(0,000$ $\leq 0,05$ ), sehingga korelasi dikatakan signifikan. Hasil koefisien determinasi, diperoleh kontibusi disiplin belajar dengan hasil belajar muatan IPS sebesar 39,4\% sedangkan sisanya 60,6\% dipengaruhi faktor lain.

Penelitian yang dilakukan oleh Minto Santoso (2015:149-158) dengan judul "Korelasi Penggunaan Media, Disiplin Belajar dan Motivasi Belajar Terhadap Prestasi Belajar IPS", mengemukakan bahwa terjadi hubungan yang sangat kuat antara penggunaan media belajar, disiplin belajar dan motivasi belajar terhadap hasil belajar sebesar 69,4\%. Penelitian lain oleh Farida Atma Apriliani dan Sutama (2017:1-9), sejalan dengan hasil penelitian ini, bahwa disiplin, fasilitas Belajar, dan monitoring orang tua memberikan kontribusi secara simultan terhadap hasil belajar Matematika melalui kemandirian sebesar $62,8 \%$

Berdasarkan penjelasan di atas dapat disimpulkan bahwa terdapat hubungan yang positif dan signifikan antara disiplin belajar belajar dengan hasil belajar muatan IPS siswa kelas IV SDN Gugus Ahmad yani Kabupaten Pekalongan. Artinya, semakin tinggi tingkat disiplin belajar siswa maka akan semakin optimal hasil belajar muatan IPS yang diperoleh dan sebaliknya.
Hubungan Minat Belajar dan Disiplin Belajar dengan Hasil Belajar Muatan IPS

Uji korelasi untuk menguji hubungan minat dan disiplin belajar dengan hasil belajar muatan IPS dalam penelitian ini menggunakan uji korelasi ganda dengan berbantuan program SPSS for Windows seri 22. Hasil perhitungan dapat dilihat pada tabel berikut:

Tabel 6 Hasil Uji Korelasi Minat Belajar dan Disiplin Belajar dengan Hasil Belajar

\begin{tabular}{cccc}
\hline $\mathbf{r}_{\text {hitung }}$ & $\begin{array}{c}\text { Taraf } \\
\text { Kesalahan }\end{array}$ & Sig. & $\begin{array}{c}\text { Uji } \\
\text { Determinasi }\end{array}$ \\
\hline 0,679 & 0,05 & 0,000 & $46,1 \%$ \\
\hline
\end{tabular}

Sumber: Data Penelitian (tahun 2020)

Tabel 6 menunjukkan bahwa uji korelasi minat belajar dan disiplin belajar dengan hasil belajar muatan IPS diperoleh hasil bahwa nilai $r_{\text {hitung }}$ yaitu 0,679 . Hasil tersebut menunjukkan angka yang positif dan nilai koefisien korelasi $(r)$ pada penelitian termasuk dalam kategori kuat. Pada taraf signifikansi 0,05 diketahui nilai signifikansi dari tabel 6 yaitu $0,000(0,000 \leq 0,05)$, sehingga korelasi dikatakan signifikan. Hasil koefisien determinasi, diperoleh kontibusi minat belajar dan disiplin belajar dengan hasil belajar muatan IPS sebesar $46,1 \%$ sedangkan sisanya $53,9 \%$ dipengaruhi faktor lain.

Hasil penelitian ini diperkuat dengan penelitian yang dilakukan oleh Drs. Isa Ansori dan Fithri, dengan judul penelitian "Hubungan Minat Belajar dan Disiplin Belajar Terhadap Prestasi Belajar Muatan Pembelajaran IPS" sejalan dengan penelitian ini. Penelitian ini disimpulkan bahwa ada hubungan yang positif dan signifikan antara minat belajar dan disiplin belajar terhadap prestasi belajar IPS, nilai $r$ hitung $=0,757$ dan termasuk kategori kuat serta berkontribusi sebesar $57,3 \%$ terhadap prestasi belajar siswa. Penelitian lain yang dilakukan Hari Indrawijaya (2018:206-215) dengan judul "Hubungan Disiplin Belajar dan Minat Belajar Dengan Hasil Belajar PKN Pada Materi Kebebasan Mengemukakan Pendapat Siswa Kelas VII DI SMPS Cinta Nusa Sentul Kabupaten Bogor". Hasil penelitian menunjukkan disiplin Belajar dan Minat Belajar secara bersama-sama berhubungan positif dan sangat kuat terhadap hasil belajar PKn (Y) pada materi kebebasan mengemukakan pendapat dengan nilai korelasi sebesar 0,951 . 


\section{SIMPULAN}

Berdasarkan hasil penelitian, maka dapat disimpulkan bahwa terdapat hubungan yang positif dan signifikan antara minat belajar dan disiplin belajar dengan hasil belajar muatan IPS siswa kelas IV SDN Gugus Ahmad Yani Kabupaten Pekalongan. Hipotesis penelitian menunjukkan ada hubungan yang signifikan dan positif antara minat belajar dan disiplin belajar dengan hasil belajar muatan IPS siswa kelas IV SDN Gugus Ahmad Yani Kabupaten Pekalongan.Hal ini ditunjukkan dari hasil analisis korelasi minat belajar dengan hasil belajar muatan IPS, nilai $r_{\text {hitung }}$ 0,646 dan termasuk dalam kategori kuat serta berkontribusi sebesar 41,7\%. Hubungan antara disiplin belajar dengan hasil belajar muatan IPS, nilai $r_{\text {hitung }} 0,628$ dan termasuk dalam kategori kuat serta berkontribusi sebesar 39,4\%. Selanjutnya hasil analisis korelasi antara minat belajar dan disiplin belajar dengan hasil belajar muatan IPS, nilai $r_{\text {hitung }} 0,679$ dan termasuk dalam kategori kuat serta berkontribusi sebesar $46,1 \%$.

\section{UCAPAN TERIMA KASIH}

Ucapan terima kasih disampaikan kepada Drs. Isa Ansori, M.Pd., sebagai dosen pembimbing, Dra. Sri Susilaningsih, S,Pd., M.Pd., sebagai mitra bestari I dan Dra. Arini Estiastuti, M.Pd., sebagai mitra bestari II yang telah memberikan bimbingan dan masukan dalam penyusunan manuskrip.

\section{DAFTAR PUSTAKA}

Anitah,Sri,dkk .2014. Strategi Pembelajaran di $S D$. Banten: Universitas Terbuka.

Ansori, Isa, dan Fithri. 2019. Hubungan Minat Belajar Dan Disiplin Belajar Terhadap Prestasi Belajar Muatan Pembelajaran IPS. Prosiding Seminar Nasional Pascasarjana UNNES. Hal 1151-1156.

Apriliani, F.A., dan Sutama. 2017. Kontribusi Sikap Disiplin, Fasilitas Belajar, Monitoring Orang Tua Terhadap Kemandirian Dampaknya Pada Hasil Belajar Matematika Siswa SMP. Seminar Nasional Pendidikan Matematika. Hal 1-9.

Baharuddin dan Wahyuni. 2015. Teori Belajar dan Pembelajaran. Yogyakarta: ArRuzz Media.

Dewantari, Tri, dan Rita E.I. 2018. Assertive training on discipline of learning in junior high school. The International Journal of Counseling and Education. 3(2): 57-62.

Indrawijaya, Hari. 2018. Hubungan Disiplin Belajar dan Minat Belajar Dengan Hasil Belajar PKN Pada Materi Kebebasan Mengemukakan Pendapat Siswa Kelas VII DI SMPS Cinta Nusa Sentul Kabupaten Bogor. Jurnal Program Studi PGMI. 5(2): 206-215.

Kumala Sari, Fitria, Rakimahwati, dan Yanti F. 2019. Hubungan Minat dengan Hasil Belajar Peserta Didik Pada Pembelajaran Matematika Kelas IV SDN 25 Jati Tanah Tinggi. Jurnal Basicedu. 3(2): 397-405.

Mulyawati, Yuli, Sumardi, dan Sri E. 2019. Pengaruh Disiplin Belajar Terhadap Hasil Belajar Ilmu Pengetahuan Sosial. Jurnal Ilmiah Pendidikan. 3(1): 14.

Nesi, Mikael, dan Maik A. 2018. Pengaruh Minat dan Pengunaan Metode Terhadap Hasil Belajar IPA Biologi Siswa Kelas VII SMP Negeri 2 Jayapura. Jurnal Pendidikan Biologi dan Sains. 1(1): 80-94.

Nuristiqomah dan Susilo. 2018. Hubungan Minat Siswa dan Lingkungan Masyarakat Terhadap Hasil Belajar IPS Kelas V. Joyful Learning Journal. 7(2): 55-63.

Peraturan Menteri Pendidikan Nasional Republik Indonesia Nomor 22 Tahun 2006 Tentang Standar Isi untuk Satuan Pendidikan Dasar dan Menengah. Jakarta: Depdiknas.

Priyatno, Duwi. 2014. Panduan Praktis Olah Data Menggunakan SPSS. Yogyakarta: ANDI.

Rismawati. 2017. Hubungan antara Disiplin Belajar dengan Hasil Belajar PPKn. Prosiding Konferensi Nasional Kewarganegaraan III. Hal 93-95.

Santoso, Minto. 2015. Korelasi Penggunaan Media, Disiplin Belajar dan Motivasi Belajar Terhadap Prestasi Belajar IPS. CENDEKIA. 9(2): 149-158.

Sugiyono. 2016. Statistika Untuk Penelitian. Bandung: Alfabeta. 
Susanto, Ahmad. 2013. Teori Belajar dan Pembelajaran. Jakarta: PRENADAMEDIA GROUP.

Triarisanti, Risa, dan Pupung Purnawarman. 2019. The Influence Of Interest And Motivation On College Students' Language And Art Appreciation Learning Outcomes. International Journal of Education. 11(2): 130-135.
Tu'u, Tulus. 2008. Peran Disiplin Pada Perilaku dan Prestasi Siswa. Jakarta: Gramedia Widiasarana Indonesia.

Wasiatul Aulia, Devika, Muhammad K., dan Masturi. 2018. Role of Learning Discipline in Mediating The Influence of Parent's Parenting Towards Student's Learning Achievement. Journal of Primary Education. 7(2): 155 162. 